\title{
Social responsibility in major newspapers coverage of "9/11 lapses" controversy
}

\author{
Hai Long Tran \\ West Virginia University
}

Follow this and additional works at: https://researchrepository.wvu.edu/etd

\section{Recommended Citation}

Tran, Hai Long, "Social responsibility in major newspapers coverage of "9/11 lapses" controversy" (2004). Graduate Theses, Dissertations, and Problem Reports. 1564.

https://researchrepository.wvu.edu/etd/1564

This Thesis is protected by copyright and/or related rights. It has been brought to you by the The Research Repository @ WVU with permission from the rights-holder(s). You are free to use this Thesis in any way that is permitted by the copyright and related rights legislation that applies to your use. For other uses you must obtain permission from the rights-holder(s) directly, unless additional rights are indicated by a Creative Commons license in the record and/ or on the work itself. This Thesis has been accepted for inclusion in WVU Graduate Theses, Dissertations, and Problem Reports collection by an authorized administrator of The Research Repository @ WVU. For more information, please contact researchrepository@mail.wvu.edu. 


\title{
Social Responsibility in Major Newspapers Coverage of “9/11 Lapses” Controversy
}

\author{
Tran Long Hai \\ Thesis submitted to the Perley Isaac Reed School of Journalism \\ at West Virginia University \\ in partial fulfillment of the requirements for the degree of
}

Master of Science in Journalism

Terry Wimmer, Ph.D., Chair

Ivan Pinnell, Ph.D.

George Esper, Ph.D.

Carol Zwickel, Ph.D.

Morgantown, WV

2004

Keywords: social responsibility, agenda setting, prior restraint, investigative journalism, 9/11, intelligence lapses 


\begin{abstract}
Social Responsibility in Major Newspapers Coverage of

“9/11 Lapses" Controversy
\end{abstract}

Tran Long Hai

This study measures major newspapers' performance in covering the "September 11 lapses" controversy against social responsibility principles. Content analysis of 535 newspaper items, published by the New York Times, Washington Post, San Francisco Chronicle, USA Today in one year (Sept. 12, 2001-Sept. 11, 2002), found the papers did not live up to journalistic precepts traditionally listed as required for the press in a democratic society. They were successful in providing a source of comprehensive and balanced information, a forum for exchange of comment and criticism on the government's losses and failures. However, major newspapers failed to aggressively pursue independent investigative journalism as a watchdog representing the people's right to know. 


\section{DEDICATION}

To my parents, Mây, Ngôong and Ái 


\section{TABLE OF CONTENTS}

LIST OF TABLES $\quad$ V

ACKNOWLEDGMENTS vi

INTRODUCTION

RESEARCH QUESTION 3

LITERATURE REVIEW

Social Responsibility Doctrine $\quad 5$

Agenda Setting as a Social Responsibility 13

$\begin{array}{ll}\text { Prior Restraint vs. Social Responsibility } & 18\end{array}$

$\begin{array}{ll}\text { HYPOTHESIS } & 22\end{array}$

$\begin{array}{ll}\text { METHODOLOGY } & 22\end{array}$

RESULTS AND DISCUSSION 29

$\begin{array}{ll}\text { CONCLUSION } & 50\end{array}$

$\begin{array}{ll}\text { APPENDIX } & 58\end{array}$

$\begin{array}{ll}\text { BIBLIOGRAPHY } & 62\end{array}$ 


\section{LIST OF TABLES}

Table

Page

1. News Frequency 31

2. Front-page Placement in News Category 32

3. Analysis of Length in News Category 33

4. Analysis of Story Treatment 35

5. Analysis of Tone in News Articles Published before May 2002

6. Analysis of Tone in Op-Ed/Commentary Articles Published before May $2002 \quad 38$

7. Analysis of View in Op-Ed/Commentary Category 39

8. Analysis of Manner of Reporting in News Category 42

9. Analysis of Sourcing in News Category 43

10. Most Published Authors in News Coverage 44 


\section{ACKNOWLEDGMENTS}

Special thanks to Dr. Terry Wimmer for guiding through the craft of this research. His advice and encouragement carried me over the barrier of language to the ground of the thinking process. I am grateful to Dr. Ivan Pinnell who, along with Dean Christine Martin, worked so hard to give me this wonderful learning and living experience. I am blessed to have him as my primary advisor. I would like to extend my sincere gratitude to Dr. George Esper for always being there to help in any way he could. Many thanks to Dr. Carol Zwickel for sitting on my thesis committee.

I am especially grateful to my family in Vietnam and Phuong, my only relative in America, for being so supportive in every step of my life.

Last but not least, I want to thank $\mathrm{Ai}$, Nhu and Nguyen whose love and patience help me grow along the way. 


\section{INTRODUCTION}

To the U.S. media, First Amendment freedom and social responsibility are the most fundamental concepts. The combination of two elements is crucial for the American press to practice its belief in the ethical mission of "truth about the fact."1

The formula functioned well during the Vietnam War era when a free and skeptical press rebelled against government secrecy and manipulation to serve the public's right to know. Watershed cases such as The Pentagon Papers, Watergate, or The Selling of the Pentagon ${ }^{2}$ set out new standards for freer and more socially responsible operation of the media.

However, this democratic trend has been going backward, rather than forward, since then. Recent surveys show ratings of the news at record lows as Americans are more dissatisfied with information quality. ${ }^{3}$ Media practitioners bitterly complained about

\footnotetext{
${ }^{1}$ Commission on Freedom of the Press, A Free and Responsible Press (Chicago: University of Chicago Press, 1947), 21.

${ }^{2}$ In 1971, with the news documentary The Selling of the Pentagon exposing massive Pentagon propaganda for increased U.S. intervention and its widespread efforts to deceive reporters about the Vietnam War, CBS became involved in a major dispute with the government. CBS was accused of distortion, biased and unpatriotic coverage of the war. The Congress, with support from the White House, believed it had the authority to investigate broadcast news, asking for outtakes of unedited film for the program, which CBS refused to provide. CBS President Frank Stanton was subpoenaed to appear before a House committee with the outtakes, he again refused, defending his action under freedom of the press. The committee voted to hold him in contempt of Congress, however, the whole House voted not to bring the charges against him. The Selling of the Pentagon established First Amendment protection for the broadcast press against a review of the edits made. It resisted the power of the government in time of war to manage the news, opposing the use of subpoenas to intimidate the press. Detailed discussion of this matter can be seen in Corydon B. Dunham, Fighting for the First Amendment: Stanton of CBS vs. Congress and the Nixon White House (Westport, Connecticut: Praeger, 1997).

${ }^{3}$ Rebecca Ann Lind, "Competing Ethos: Reliance on Profit Versus Social Responsibility by Laypeople Planning a Television Newscast," Journal of Broadcasting and Electronic Media 45, no. 1 (Winter 2001): 118-134.
} 
the government's increased control of the press in the wake of Vietnam. They contended that the blame game against the news media for U.S. failure in the conflict drove succeeding governments to various attempts to withhold or censor information, thus hindering the watchdog role of the press. ${ }^{4}$ Meanwhile, media critics charged that the profit-driven corporate media failed to aggressively check on those government agencies that serve elite interests, leading to a decline of journalism as a public service. ${ }^{5}$ Citing examples of the abuse of the press freedom to publish with disregard for truth as evidence, some even questioned the ethical credibility of the news media, accusing them of contempt of the public. ${ }^{6}$

These arguments raise a noteworthy question to be considered: how should the social responsibility theory be tested under current circumstances with the erosion of First Amendment and civic principles? To measure the performance of today's press in its socially responsible role, case studies should be conducted with the focus on the use of investigative journalism to track down major stories of public interest. As part of the

\footnotetext{
${ }^{4}$ Stanley W. Cloud, “The Pentagon and the Press,” Nieman Report 55, no.4 (Winter 2001): 13-16.

${ }^{5}$ Robert W. McChesney, Rich Media, Poor Democracy: Communication Politics in Dubious Times (Urbana \& Chicago: University of Illinois Press, 1999), 15-77.

${ }^{6}$ The most cited case has been the notorious scandal in 1980, when Janet Cooke of the Washington Post was forced to surrender her Pulitzer Prize after it was disclosed that her prize-winning investigative story about an eight-year-old heroin addict named "Jimmy" was a phony. Recently, the controversial debate over media credibility reemerged to public attention, when Jayson Blair of the New York Times acknowledged that he fabricated and plagiarized quotes in numerous stories. Rob Anderson, Robert Dardenne, and George M. Killenberg, The Conversation of Journalism (Westport, Connecticut: Praeger, 1994), 182-184; Howard Kurtz, "More Reporting By Times Writer Called Suspect" Washington Post, 8 May 2003, sec. C, p. 1
} 
efforts, this research examines how leading newspapers served the public with information on a typically emotional issue at a sensitive time. Observations from the perspective of an exemplary scenario, to some extent, will contribute a close look into the current nature of press operation in the framework of social responsibility ideals.

\section{RESEARCH QUESTION}

Because of the magnitude of the story itself, the most compelling question asked in the wake of September 11 is why it had happened. Though various factors surrounded the tragic events should be considered, it is true to contend that the inability to prevent the terrorist plot was the worst embarrassment to the U.S. intelligence community. However, for months after the attacks, U.S. leaders insisted they had no warnings to prepare for them. The case then became a controversial issue when leaked information in May $2002^{7}$ revealed the government's failure to act on alarming signals prior to September 11. Given the circumstances, the U.S. media were required by the social responsibility theory to perform the ethical duty to find out the whole truth. In other words, they should play the watchdog role to serve the people's right to know.

But the September 11 tragedy also involved other sensitive factors that hindered aggressive efforts of investigative journalism. Americans have never had such massive loss of life where civilians were attacked by terrorists on American soil. While the

\footnotetext{
${ }^{7}$ The timeline is detailed in Appendix.
} 
public's desire to have the "why" question answered was real, Americans somehow endorsed wartime censorship, ${ }^{8}$ the government maximized efforts to withhold and manipulate information, and the media saw the special need to exercise self-restraint. ${ }^{9}$ The unique situation was a fair opportunity for the government to wield patriotism and national security in wartime against critical reporting. ${ }^{10}$

Historically, the performance of leading newspapers at critical times testified to their preeminence as independent institutions representing the public to hold government accountable. Watershed cases such as The Pentagon Papers or Watergate in the 1970s produced various legendary examples of how daring journalists fought against and prevailed over the government's lies and concealments. Major newspapers of national record like the New York Times, Washington Post, San Francisco Chronicle, USA Today have long been among the most important sources of information to foster public understanding of divisive issues. Thanks to their excellence in reporting efforts, the New York Times and Washington Post remain in the top list of Pulitzer winners each year. In the era of media convergence, the two elite newspapers continue to assume the agendasetting function for the press. ${ }^{11}$ The San Francisco Chronicle is the largest newspaper in Northern California and the second largest on the West Coast, reaching 1.25 million

\footnotetext{
${ }^{8}$ Al Cross, “'New America’ May Forget Old Values,” Quill 90, no. 1 (January/February 2002): 4.

${ }^{9}$ Gina Barton, Beverly Campbell, "Patriotism and the News," Quill 89, no. 10 (December 2001): 18-21.

${ }^{10}$ Maria Trombly, "Ethics and War,” Quill 89, no. 10 (December 2001): 14-17.

${ }^{11}$ Ben H. Bagdikian, The Media Monopoly, 6th ed., (Boston: Beacon Press, 2000), viii-xlvii.
} 
readers daily. With its giant circulation of 2.2 million, the USA Today, in one way or another, has disproportionate influence over the public and national events.

With revelations of intelligence lapses prior to September 11, major newspapers once again faced the moment of truth to test their vitality as the Fourth Estate at public service.

How did major newspapers provide news coverage of the issue?

How did they foster public understanding and discussion about the controversy?

How did they use investigative journalism?

How did they serve the public's right to know?

This case study of leading newspapers' work on the major story will offer an insight into the typical application of social responsibility principles as it is in the operation of today's press.

\section{LITERATURE REVIEW}

\section{Social Responsibility Doctrine}

To understand the performance of contemporary newspapers from the perspective of social responsibility doctrine, it is necessary to precede with an overall review of the evolution of the theory. This will provide the theoretical context for the study to be conducted.

In the media world, the term social responsibility has been widely used as a philosophy, or a doctrine of press operation. It is a normative theory that describes the 
news media's ideal function or a set of ideas of how the media do and should perform. It is believed that the social responsibility theory developed in the 20th century in the United States, evolving from professional principles set by media practitioners, media codes, and especially the work of the Commission on Freedom of the Press (Hutchins Commission). ${ }^{12}$ But, according to J. Herbert Altschull, social responsibility is "an ancient doctrine, one that had already been alluded to the writings of Plato and Aristotle, one that has been reaffirmed in every generation since (John) Milton."13 The work of the Hutchins Commission, he observed, had written the term social responsibility with modern meaning into the world of the U.S. media. ${ }^{14}$

In 1947, with the published report A Free and Responsible Press this group made social responsibility a formalized concept of media operation. The Commission encouraged greater responsibility of the press and more surveillance from the informed public to check on its improved performance. It set five crucial requirements for the press, which should provide the public with:

- $\quad$ a truthful, comprehensive, and intelligent account of the day's events in a context that gives them meaning, truth about the fact;

- $\quad$ a forum for exchange of comment and criticism;

- $\quad$ a representative picture of the constituent groups in society;

- $\quad$ the representation and clarification of the goals and values of the society;

\footnotetext{
${ }^{12}$ Werner J. Severin, James W. Tankard, Jr., Communication Theories: Origins, Methods, and Uses in the Mass Media, 5th ed. (New York: Addison Wesley Longman, 2001), 314.

${ }^{13}$ J. Herbert Altschull, From Milton to McLuhan: The Ideas Behind American Journalism (New York \& London: Longman, 1990), 285.

${ }^{14}$ J. Herbert Altschull, Agents of Power: The Role of the News Media in Human Affairs, 1st ed. (New York \& London: Longman, 1984), 180.
} 
- $\quad$ full access to the day's intelligence for every member of the society. ${ }^{15}$

With the publication of Four Theories of the Press in 1956, social responsibility was officially called a media theory in the classification of the world's press systems based on the press-government relationship (others included authoritarian, libertarian and Soviet communist doctrines). Theodore Peterson reset functions of the press under social responsibility theory as follows:

- $\quad$ servicing the political system by providing information, discussion and debate on public affairs;

- $\quad$ enlightening the public so as to make it capable of self-government;

- $\quad$ safeguarding the rights of the individual by serving as a watchdog against government;

- $\quad$ servicing the economic system, primarily by bringing together the buyers and sellers of goods and services through the medium of advertising;

- $\quad$ providing entertainment;

- $\quad$ maintaining its own financial self-sufficiency so as to be free from the pressure of special interests. ${ }^{16}$

In his Agents of Powers in 1984, Altschull claimed social responsibility was an absurd term "devoid of meaning," whose content was "so vague that almost any meaning can be placed upon it." 17 Though social responsibility has been perceived as a vital principle in the media's system of values, the term itself has never been available in dictionaries due to its obscure origin and abstract nature. The author rejected the notion expressed in Four Theories of the Press that social responsibility only existed as a

\footnotetext{
${ }^{15}$ Commission on Freedom of the Press, A Free and Responsible Press, 21-28.

${ }^{16}$ Fred S. Siebert, Theodore Peterson, Wilbur Schramm, Four Theories of the Press (Urbana: University of Illinois Press, 1956), 74.

${ }^{17}$ Altschull, Agents of Power, 301-305.
} 
doctrine of media operation in Anglo-American societies.

"No authority wants its press to practice just any kind of social responsibility," he wrote. "What is wanted is the kind of social responsibility that suits a particular conception of the social order." ${ }^{18}$ According to Atschull, today there are three models of the press (Market, Marxist, and Advancing), all of which endorse the socially responsible role, but in different ways.

His definitions of these models --based on comparisons of purposes of journalism, articles of faith, and views on press freedom-- went as follows:

MARKET MODEL

Purposes of Journalism

- $\quad$ to seek truth

- $\quad$ to be socially responsible

- $\quad$ to inform (or educate) in a non-political way

- $\quad$ to serve the people impartially; to support capitalist doctrine

- $\quad$ to serve as watchdog of government

Articles of Faith

The press:

- $\quad$ is free of outside interference

- $\quad$ serves the public's right to know

- $\quad$ seeks to learn and present the truth

- $\quad$ reports fairly and objectively

Views on Press Freedom journalists are free of all outside controls

- $\quad$ the press is not servile to power and is not manipulated by power

- $\quad$ no national press policy is needed to insure a free press

${ }^{18}$ Ibid., 201-204. 
MARXIST MODEL

Purposes of Journalism

- $\quad$ to search for truth

- $\quad$ to be socially responsible

- $\quad$ to educate the people and enlist allies (in a political way)

- $\quad$ to serve the people by demanding support for socialist doctrine

- $\quad$ to mold views and change behavior

\section{Articles of Faith}

The press:

- $\quad$ transforms false consciousness and educates workers into class consciousness

- $\quad$ provides for objective needs for the people

- $\quad$ facilitates effective change

- $\quad$ reports objectively about the realities of experience

\section{Views on Press Freedom}

- $\quad$ a free press means that the opinions of all people are published, not only those of the rich

- $\quad$ a free press is required to counter oppression

- a national press policy is required to guarantee that a free press takes the correct form

\section{ADVANCING MODEL}

\section{Purposes of Journalism}

- $\quad$ to serve truth

- $\quad$ to be socially responsible

- $\quad$ to educate (in a political way)

- $\quad$ to serve the people by seeking, in partnership with government, change for beneficial purposes

- $\quad$ to serve as an instrument of peace

\section{Articles of Faith}

The press is:

- a unifying and not a divisive force

- $\quad$ a device for beneficial social change

- $\quad$ an instrument of social justice

- $\quad$ meant to be used for two-way exchanges between journalists and readers

\section{Views on Press Freedom}

- $\quad$ a free press means freedom of conscience for journalists

- $\quad$ press freedom is less important than the viability of the nation 
- $\quad$ a national press policy is needed to provide legal safeguards for freedom. ${ }^{19}$

In relation to social responsibility doctrine, Atschull reached the following conclusions:

In all three movements of the symphony, the press is assigned the purpose of serving the people. This service is described in different terms. To those who believe in the virtue of the market system of economics, the news media meant to support that system; to those who believe in Marxism-Leninism, the media are meant to support socialist doctrine. In the market image, the press is seen as operating outside the control of government, as a watchdog, or even a kind of adversary of the government. In the Marxist image, the press is the creature of the government (or the Party), endorsing its actions and seeking to persuade its readers and viewers to the same kind of endorsement. Among the advancing nations, however, the image is different: It is of news media that serve as partners of government. $^{20}$

We can say that the serious American press as a whole is convinced that what it is doing, it is doing in the interests of the public, the public that has a right to know what is going on in the public life in order to carry out its duties as citizens, thereby fulfilling the democratic assumption... The Marxist articles of faith assert the belief that the news media in Marxist society serve the needs and the interests of the masses... In the advancing world, efforts have been undertaken to bring about a more horizontal pattern. ${ }^{21}$

All press systems endorse the doctrine of social responsibility, proclaim that they serve the needs and interests of the people, and state their willingness to provide access to the people. ${ }^{22}$

After almost forty years, in retrospect, the University of Illinois published Last

\footnotetext{
${ }^{19}$ Ibid., 279-299.

${ }^{20}$ Ibid., 285-286.

${ }^{21}$ Ibid., 289-290.

${ }^{22}$ Ibid., 298.
} 
Rights: Revisiting Four Theories of the Press to give a final word on the relevance of

Four Theories of the Press in the era of media convergence. Reviewing theoretical shortcomings, internal inconsistencies and inadequacies, the authors came to the conclusion that social responsibility was formulated as a normative theory of press operation without rigorous examination and testing of hypotheses. Additionally, the book offered a new look at social responsibility as a complex of different theories with conservative, moderate, and radical models included in its simplest form of combination.

The authors put:

In fact, social responsibility theory seems to contain within it several different theories. We can identify at least three.

First, there is a conservative model. This calls for limited adjustments "Let's just all try a little harder to be fair"- to forestall more radical proposals. Such a call for socially responsible media is little different from the enlightened libertarianism that characterizes mainstream advertising practices. It expects media to remain primarily market- and profit-driven.

A second, moderate model calls for the profit motive to be severely curtailed but only in the presentation of news and opinion. The moderate position wants a benevolent elite of expert professional journalists to be insulated from the crasser concerns of media owners and thus to be free to serve a public that is, of course, also crass but not as canny as the wealthy and powerful. Thus, a protected community of professionals will allow a larger competitive, individualistic society to operate with a modicum of fairness.

A third, radical model calls for transformation of the greater society itself. Instead of responsible media serving an essentially individualistic, competitive public, they should be engaged in supporting and creating a communitarian public. Indeed, truly responsible media can exist only in the context of real communities, communities conceived of as not just based on geographical proximity of superficial interactions among individuals but as the shared creation of a common life, culture, or identity (Christians, Ferre, and Fackler 1993).

These three models meet the standards and requirements of social responsibility theory. While they seem only marginally compatible with each other, they still share some characteristics, especially on the level of policy. They all hope for change to come from moral behavior rather than government action. 
They all worry at least a little about the ability of the "free market" to resolve social conflict. And they all decline to demand structural change in media industries - even though the communitarians come close. ${ }^{23}$

By 1995, in The Power of News, Michael Schudson made his own list of seven responsibilities for the press to fulfill in democracy. They included:

- $\quad$ to provide citizens fair and full information so they can make sound decisions;

- $\quad$ to provide coherent frameworks to help citizens comprehend the complex political universe;

- $\quad$ to serve as common carriers of the perspectives of the varied groups in society;

- $\quad$ to provide the quantity and quality of news that people want;

- $\quad$ to represent the public and speak for and to the public interest in order to hold government accountable;

- $\quad$ to evoke empathy and provide deep understanding so that citizens can appreciate the situation of other human beings in the world and so elites can come to know and understand the situation of other human beings, notably nonelites, and learn compassion for them;

- $\quad$ to provide a forum for dialogue among citizens that not only informs democratic decision making but is, as process, an element in it. ${ }^{24}$

Though social responsibility is a theory that describes the news media's ideal function rather than an empirically tested one, its application has been highly developed both in professional practices and academic studies. For media practitioners, social responsibility is one of the most fundamental principles in the press' system of ethical and professional values. As to media researchers, the theory is the helpful guide to assess the performance of the news media in accommodating public expectations in democratic

\footnotetext{
${ }^{23}$ William E. Berry et al., Last Rights: Revisiting Four Theories of the Press, ed. John C. Nerone (Urbana: University of Illinois Press, 1995), 122-123.

${ }^{24}$ Michael Schudson, The Power of News (Cambridge, MA: Harvard University Press, 1995), 28-29.
} 
societies. This research proposes using social responsibility as the standard tool to measure major newspapers' efforts to meet the demand of credible and accountable journalism at a critical time.

\section{Agenda Setting as a Social Responsibility}

In order to see how well newspapers of national record fulfilled their socially responsible obligations to the people in need of information on an emotional issue, attention should be paid to an important point: how did they perform in fostering public understanding and discussion about the subject? By charging the press with the role of providing "intelligent account of the day's events," 25 "enlightening the public," 26 social responsibility theory had envisioned the agenda setting function of the press even before the term was established in the early 1970s.

The agenda-setting hypothesis began with Maxwell E. McCombs and Donald L. Shaw in $1972^{27}$ as an antithesis to the limited-effect theoretical position that was dominant in mass communication research at the time. It was a breakthrough development of the ideas set our by precursors (Walter Lippman, ${ }^{28}$ Norton E. Long, ${ }^{29}$

\footnotetext{
${ }^{25}$ Commission on Freedom of the Press, 21.

${ }^{26}$ Siebert, Peterson, Schramm, Four Theories of the Press, 74.

${ }^{27}$ Maxwell E. McCombs, Donald L. Shaw, "The Agenda-Setting Function of Mass Media," Public Opinion Quarterly 36, no. 2 (summer 1972): 176-187.

${ }^{28}$ Walter Lippman, Public Opinion (New York: McMilan, 1922; reprint, New York: The Free Press, 1965)

${ }^{29}$ Norton E. Long, "The Local Community as an Ecology of Games," American Journal of Sociology 64 (1958): 251-261.
} 
Kurt Lang and Gladys Engel Lang, ${ }^{30}$ and Bernard C. Cohen ${ }^{31}$ ) that the media had the capability, through repeated news coverage, of raising the importance of an issue in the public's mind. Since then, the agenda-setting hypothesis has been expanded and become one of the most influential in modern mass communication research. ${ }^{32}$ Hundreds of studies have been conducted to cover various aspects of the agenda-setting process. With the emphasis on how the media agenda is set, how the public agenda influences the policy agenda, ${ }^{33}$ the research literature has thoroughly addressed such questions as:

- $\quad$ relationship between news coverage and public perception of the importance of the issues;

- $\quad$ media coverage and reality;

- $\quad$ causal relationship between media agenda and public agenda;

- $\quad$ priming process in which the media attend to some issues and not others and thereby alter the standards by which people evaluate election candidates;

- $\quad$ obtrusiveness of the issue as a factor in agenda setting process;

- $\quad$ abstract and concrete issues in agenda setting;

- $\quad$ time needed for agenda setting;

- $\quad$ the role of media exposure;

- $\quad$ the need for orientation;

- $\quad$ who set the media agenda;

- $\quad$ media agenda and policy agenda;

- $\quad$ how does agenda setting work;

\footnotetext{
${ }^{30}$ Kurt Lang, Gladys Engel Lang, "The Mass Media and Voting," in American Voting Behavior, eds. E. Burdick, A. J. Brodbeck (Glencoe, Ill.: The Free Press, 1959), 217-235.

${ }^{31}$ Bernard C. Cohen, The Press and Foreign Policy (Princeton, N.J.: Princeton University Press, 1963$), 13$.

${ }^{32}$ David K. Perry, Theory and Research in Mass Communication: Contexts and Consequences, 2 nd ed. (Mahwah, New Jersey: Lawrence Erlbaum Associates Publishers, 2002), 207.

${ }^{33}$ Shearon A. Lowery, Melvin L. DeFleur, Milestones in Mass Communication Research: Media Effects, 3d ed. (New York: Longman Publishers USA, 1995), x.
} 
- $\quad$ second level of agenda setting. ${ }^{34}$

Among recent works concerning agenda setting function of the press, some have been advancing "beyond the study of the formation of agendas by the press to consider how ideas of agenda setting might be applied in ways to make society work better." ${ }^{35}$ In reality, the concept of agenda setting is much related to the values and beliefs used by journalists to determine the responsibility of the press in providing the society with proper information. For that reason, proponents of this academic approach argued that democracy requires that the media engage in "meaningful agenda setting." Shaw and some other scholars such as S. E. Martin, R. F. Carter, K. R. Stamm, and K. Heintz-Knowles suggested using the study of agenda setting to encourage the media to better serve the public through the agenda setting function. ${ }^{37}$

Jay Rosen and A.C. Shepard, leading members of the avant-garde movement, even recommended the notion of public journalism, or civic journalism, as a practical application of agenda-setting theory. This kind of journalism, they argued, would be committed to serving the community better by identifying the important issues and

\footnotetext{
${ }^{34}$ Severin, Tankard, Jr. , Communication Theories, 219-244.

${ }^{35}$ Ibid., 242.

${ }^{36}$ M. Gurevitch, J.G. Blumler, "Political Communication Systems and Democratic Values," in Democracy and the Mass Media, ed. J. Lichtenberg (Cambridge, Eng.: Cambridge University Press, 1990), 269-289.

${ }^{37}$ Detailed discussions of this matter can be seen in Journalism Quarterly 69 (1992): 868-877, and 902920 .
} 
appropriately focusing on the public agenda. ${ }^{38}$ Some scholars believe civic journalism broadens the concept of journalistic social responsibility into a more active role. ${ }^{39}$

In 1983, with the suggestion of agenda building as an expanded concept of agenda setting, the Langs contributed a new step forward in the evolution of research literature. Their work, The Battle for Public Opinion: The President, the Press and the Polls During Watergate ${ }^{40}$ is as much important for another reason: for the first time ever, researchers studied the role of the press as an agenda setter during a major crisis with its coverage of government misdoings (Watergate).

Since the late 1980s, some scholars have focused on the influences on media content, and they found that the elite media have the capability of setting on agenda for other media. L. H. Danielian and S. D. Reese defined this process as "intermedia agenda setting" and noted that the New York Times is the most influential intermedia agenda setter which can lead other media and shape media content. ${ }^{41}$

By 1992, in his Media and Apocalypse: News Coverage of the Yellowstone Forest

\footnotetext{
38 Jay Rosen, "Politics, Vision, and the Press: Toward a Public Agenda for Journalism," in The New News $v$. the Old News: The Press and Politics in the 1990s, eds. J. Rosen and P. Taylor (New York: The Twentieth Century Fund, 1992), 1-33; A. C. Shepard, "The Gospel of Public Journalism," American Journalism Review 16 (1994): 28-35.

${ }^{39}$ Peter Gade et al., “Journalists' Attitudes Toward Civic Journalism Media Roles," Newspaper Research Journal 19, no. 4 (Fall 1998): 13-26.

${ }^{40}$ Gladys Engel Lang, Kurt Lang, The Battle for Public Opinion: The President, the Press and the Polls During Watergate (New York: Columbia University Press, 1983).

${ }^{41}$ L.H. Danielian, S. D. Reese, "A Closer Look at Intermedia Influences on Agenda Setting: The Cocain Issue of 1986," in Communication Campaigns About Drugs: Government, Media, and the Public, ed. P. J. Shoemaker (Hillsdale, N.J.: Lawrence Erlbaum, 1989), 47-66.
} 
Fires, Exxon Valdez Oil Spill, and Lora Prieta Earthquake, Conrad Smith provided the research literature with a clear evidence that policy makers' most important sources of information after sudden events are the New York Times and Washington Post. ${ }^{42}$

With special emphasis given to the study of agenda setting after sudden disasters, Thomas A. Birkland recently introduced the theory of "focusing events as factors in agenda setting."43 The researcher divided what he called focusing events into three categories:

- "normal" focusing events that can be expected to happen sometime such as earthquakes, hurricanes, oil spills, and nuclear plant accidents;

- " "new" focusing events that have never happened before, or have happened so long as to have faded from memory. They are novel or near-novel and may lead to the predictable search for blame. Three examples of this category are the Tylenol poisoning incident in the early 1980s, the loss of the space shuttle Challenger in 1986, and the terrorist bombing of a federal building in Oklahoma City in 1995;

- " common events under uncommon circumstances" are generally common events, such as accidents, that gain greater attention due to some unique and unusual feature. ${ }^{44}$

According to Birkland, focusing events are "so hard to keep off the agenda, and, by definition, will become more difficult to contain as they gain broader attention." ${ }^{45}$ In observation of the work of the press in the wake of such events, he made some significant

\footnotetext{
${ }^{42}$ Conrad Smith, Media and Apocalypse: News Coverage of the Yellowstone Forest Fires, Exxon Valdez Oil Spill, and Lora Prieta Earthquake, (Westpoint, Conn.: Greenwood Press, 1992), 9.

${ }^{43}$ Thomas A. Birkland, After Disaster: Agenda Setting, Public Policy, and Focusing Events, Washington, D.C.: Georgetown University Press, 1997), 3.

${ }^{44}$ Ibid., 145-147.

${ }^{45}$ Ibid., 25.
} 
points related to its agenda-setting role after major disasters:

There is often little need for groups to provoke the press into immediate coverage of a major dramatic event. The drama and novelty of a potential focusing event is often sufficient to elevate the issue on the media agenda. This is an important difference between potential focusing events and "media events" that are largely preplanned by contenders in a political controversy. Over the long term, groups that want policy change must exploit a potential focusing event to keep the issue fresh and relatively high on the agenda, lest the problem recede from the media and institutional agendas. But in the immediate term -three to six months after the event- news coverage of the problem revealed by the event will be easily discernible and at a significantly greater level than before the event. ${ }^{46}$

These insights can add more depth to a research of how major newspapers covered a typically emotional issue at a sensitive time, more specifically, the "September 11 lapses" in the wake of the terrorist attacks.

\section{Prior Restraint vs. Social Responsibility}

Social responsibility doctrine emphasizes the role of the press as "national conscience" and "protagonist for the people in keeping their rulers responsible and honest." ${ }^{47}$ The theory envisions the socially responsible operation of the press, which is expected to use its freedom to check on government as a public watchdog. In the framework of social responsibility principles, the function of the press is to question, pry and criticize government actions and inactions in assistance of American self-

\footnotetext{
${ }^{46}$ Ibid., 31.

${ }^{47}$ Elmer E. Cornwell, Jr., The Presidency and the Press, (Morristown, N.J.: General Learning Press, 1974), 3.
} 
government. $^{48}$

While First Amendment protections provide the U.S. media with immense power to act independently and free from government regulation of news content, there still are rational limits on investigative journalism when national security is at stake. ${ }^{49}$ Studies of free press in the United States suggest that the desire for those limits or other kinds of restraint has often arisen during times of insecurities about the survival of the nation and of its democratic system. ${ }^{50}$ In the meantime, researchers also contend that one barometer of speech freedoms in society is whether those freedoms exist even in times of national crisis. $^{51}$

Therein lies the problem that tests the viability of the ideas of social responsibility theory. For some special reason, prior restraint can be seen as necessary protection of society despite its contradiction of First Amendment principles, whereas the press may have to surrender its vital role of serving the people's right to know despite its uncompromising integrity. The conflict is also joined between the government's need to gain public support for emergency efforts and the belief of the press that its most important function is to ferret out and report the truth. ${ }^{52}$

\footnotetext{
${ }^{48}$ Robert A. Liston, The Right to Know: Censorship in America, (New York: Franklin Watts, Inc., 1973), 109-110.

${ }^{49}$ Ibid., 7.

${ }^{50}$ Patrick Garry, An American Paradox: Censorship in a Nation of Free Speech, (Westport, Connecticut: Praeger, 1993), 133.

${ }^{51}$ Ibid., 17.

${ }^{52}$ Liston, The Right to Know, 113
} 
Though it has been established in the watershed case Near v. Minnesota ${ }^{53}$ since 1931 that the chief purpose of the constitutional guaranty would be to prevent previous restraints upon publication, prior restraints continued to be exerted though time.

According to many media law experts, during the last several years, government attempts to use prior restraint have taken place with almost predictable regularity, especially when some form of crisis occurs. ${ }^{54}$ Cited the need for confidentiality as vital for what is called the greater good (i.e., national survival), U.S. administrations have tended to increase pressures to keep information from the people, regardless of their right to free flow of information. Court decisions have discouraged government pre-publication censorship, but confirmed that protection as to prior restraint would not be absolutely unlimited. ${ }^{55}$ In The Pentagon Papers case, which has been considered as one of the biggest victories for the press, the Supreme Court even made clear that freedom to publish did not absolve the New York Times and the Washington Post from the risk of criminal prosecution for revealing government secrets. For the first time in American history, federal court decisions found acceptable for some kinds of pre-publication

\footnotetext{
${ }^{53}$ Near v. Minnesota, 283 U.S. 697 (1931).

${ }^{54}$ Dwight L. Teeter, Jr., Bill Loving, Law of Mass Communications: Freedom and Control of Print and Broadcast Media, 5th ed. (New York: Foundation Press, 2001), 45.

${ }^{55}$ Ibid., 47.
} 
censorship. ${ }^{56}$

Research literature in each decade since the 1970s found that prior restraint would assume so many guises that it "cannot safely be said that battles against pre-publication controls are ever won, once and for all time." ${ }^{.57}$ Since the end of the Vietnam War, when the press collided with government bent on protecting its own interest and functions through prior restraint, ${ }^{58}$ government pre-publication censorship has become less dramatic, but more diverse and more sophisticated. As the government increased attempts to use secrecy and national security as obstacles to information access, the news media found themselves "hog-tied and blindfolded, utterly unable to provide the public with truth." 59

In the wake of September 11, with controversial disclosures of intelligence lapses prior to terrorist attacks, the U.S. press faced the moment of truth to carry out its mission of public service. In the meanwhile, the event provides a means to examine if the social responsibility theory that describes the news media's ideal function can be tested in its exemplary collision with prior restraint and self-censorship inspired by patriotism.

\footnotetext{
${ }^{56}$ William E. Porter, Assault on the Media: The Nixon Years (Ann Arbor: The University of Michigan Press, 2001), 234.

${ }^{57}$ Teeter, Jr., Loving, Law of Mass Communications, 71.

${ }^{58}$ Ibid., 48.

${ }^{59}$ Cloud, "The Pentagon and the Press," 13-16.
} 


\section{HYPOTHESIS}

Given the magnitude of September 11 and its aftermath, the reporting of and the investigation into missed signals leading up to terrorist attacks tested the vitality of leading newspapers as independent institutions representing the people to keep the government honest and accountable. Examining their work on the divisive issue, this research project argued:

H1: Major newspapers provided adequate information to help foster public understanding and discussion about the "September 11 lapses" controversy.

H2: Major newspapers provided balanced reporting and a forum for exchange of diverse ideas on the issue.

H3: Major newspapers played the active role of investigative journalism to serve the people's right to know. These newspapers, as a public watchdog, aggressively checked on losses and failures against government secrecy.

H4: Major newspapers met criteria listed as required to live up to the established theory of social responsibility.

\section{METHODOLOGY}

The principal and ultimate objective of the research project is to test the social responsibility theory by evaluating the manner in which major newspapers, the New York Times, Washington Post, San Francisco Chronicle and USA Today, covered the "September 11 lapses" controversy.

In this research, social responsibility means a set of journalistic precepts 
traditionally accepted as criteria to assess how the press performs in a democratic society.

They are:

To provide a truthful, comprehensive and intelligent account of the day's events, ${ }^{60}$ including information, discussion and debate on public affairs; $;{ }^{61}$

To form a forum for exchange of comment and criticism; ${ }^{62}$

- $\quad$ To provide full access to the day's intelligence for every member of the society ${ }^{63}$ and serve as the common carriers of the perspective of the varied groups in society; ${ }^{64}$

- $\quad$ To enlighten the public ${ }^{65}$ to help citizens comprehend the complex political universe; ${ }^{66}$

- $\quad$ To safeguard the rights of individual by serving as a watchdog against government; ${ }^{67}$

- $\quad$ To represent the public and speak for and to the public interest in order to hold government accountable. ${ }^{68}$

The reason for choosing the New York Times, Washington Post, San Francisco Chronicle, USA Today is based on the following propositions. Among powerful newspapers across the nation, the New York Times, Washington Post, San Francisco Chronicle, USA Today decidedly shape the way each major story of national concern is

\footnotetext{
${ }^{60}$ Commission on Freedom of the Press, 21.

${ }^{61}$ Siebert, Peterson, Schramm, 74.

${ }^{62}$ Commission on Freedom of the Press, 23.

${ }^{63}$ Ibid., 28.

${ }^{64}$ Schudson, The Power of News, 29.

65 Siebert, Peterson, Schramm, 74.

${ }^{66}$ Schudson, 28.

${ }^{67}$ Siebert, Peterson, Schramm, 74.

${ }^{68}$ Schudson, 29.
} 
reported. Top Pulitzer winners -the New York Times and Washington Post- and San Francisco Chronicle, which is known as the "Voice of the West," are part of the prestige press from coast to coast. They serve as the most authoritative source of information and the conscience of American journalism. USA Today, a Gannett newspaper, earns popular reputation thanks to its largest readership in the land. The four newspapers constitute an important force, whose voice has disproportionate influence over the public, the media, national leaders, and national events. They are natural subjects for any research on contemporary major newspapers.

This study involved a content analysis in one year of coverage (September 12, 2001-September 11, 2002) of the government's failure to heed attack signs and the investigation into what was not done to prevent the terrorist plot. Given that the story came to dominate the media agenda in May and June 2002, ${ }^{69}$ the time frame offers insights into what leads the major newspapers followed and how far they followed them.

The research carried out various pilot tests to develop search terms for locating a census of full text, relevant stories on the Lexis-Nexis database. It administered a series of computerized literature searches using the terms Sept. 11, intelligence, along with F.B.I., C.I.A., security, alarm, alert, warning, signal, lapse and failure as key words in gathering data.

The sample for each newspaper was open to news and Op-Ed/Commentary items of any type or length, as long as they mainly focused on or specifically mentioned to the

\footnotetext{
${ }^{69}$ See timeline in Appendix.
} 
"missed signals" story. These included discussions on government's inability to foil the terrorist plot, intelligence failure, ignorance of attack signs, and the probe into the September 11 lapses. Weekly reviews were generally excluded with the exception of those items that could stand out as independent pieces to offer in-depth comments on the subject. Non-news items including captions for graphics and photographs, excerpts from statements or interviews, charts, facts and figures were discarded. Given these considerations, the research selected 535 newspaper items for analysis, including 192 articles from the New York Times; 178 by Washington Post; 88 from USA Today; and 77 by San Francisco Chronicle.

This study set out to weigh the balance of the newspapers' coverage in the debate over the "September 11 lapses" by attending to the time element and its corresponding implications in news frequency, front-page placement, story treatment, story length, sourcing, and author. In addition to manifest analysis, the research took further attempts at latent analysis to evaluate if the New York Times, Washington Post, San Francisco Chronicle, and USA Today lived up to the assumed role of social responsibility. These included the use of tone and independent investigative reporting to set an agenda for the news media, the diversity of views expressed in Op-Ed/Commentary items (i.e., editorials, letters to editor, columns, commentaries.)

Each coding category was analyzed according to a classification scheme, by which a particular operational definition was employed.

New frequency was defined as the number of times "missed signals" stories were repeated in a given period. 
Front-page placement means front-page space given to top stories of the day. Every news article started on the front page was counted as a front-page story, and this rule also applied to news items with a sky box on the front page.

Story treatment (or genre) was defined as the way each newspaper item was written. Any article that emphasized facts (e.g. straight news, in-depth news analysis, or news feature) was coded as a news story, while each item that offered a first-person opinion or a stated opinion of the newspaper (e.g. editorial, letter to editor, column, commentary) was considered as an Op-Ed/Commentary article.

Analysis of story length only considered news articles. To determine if a news item is a long story, coders were instructed to use the 1,000-word limit to measure up. Accordingly, medium articles range from 500 to 999 words, and short ones are under 500 words.

The sampling frame for author analysis was news category. Names of authors were counted every single time they appeared on the byline of a story. When an article was co-authored, it should be attributed to each individual.

Manner of reporting means how the reporter used his or her efforts to cover news. The context in which information was gathered and reported reveals how hard the reporter tried to dig the story out. Only items coded as news stories were part of the sample, while coders, depending on whether information was gathered from public events (i.e., hearings, news conferences...) or by investigative efforts (i.e., special arrangements to reach out for exclusive news), were asked to identify them either as event-based or original reporting articles. In cases where independent attempts were made to further the 
so-called "continuing news," ${ }^{, 70}$ they were not classed with original reporting items, but with event-based group. Continuing news here means a series of stories following up a major dramatic event in one week since it comes to dominate media agenda.

The sampling frame for sourcing analysis was news articles. Both named and anonymous sources were taken into account as long as they provided relevant opinion or information on the subject in a direct quote, partial quote, attributed statement, or paraphrase. This research did not seek to know what the sources said. Instead, it examined the use of original sources against the reliance on sources from public events and information from other media. The point of analysis is to compare the percentages scored by each kind of source in the sample. Original sources were defined as individuals who responded to exclusive interviews, or unique documents obtained by investigative efforts. In cases where statements or documents were recorded without any special arrangements (e.g. in a news conference, televised address, or hearing) they should be attributed to sources from public events. These also include information, statements or opinions exclusively quoted by a newspaper to give more details on a public event. When relevant information was cited from any other news organizations (not the home newspaper,) it should be credited to other media sources.

View analysis: This study tracked different patterns of views expressed in OpEd/Commentary items (i.e., editorials, letters to editor, columns, commentaries) to

\footnotetext{
${ }^{70}$ Randall S. Sumpter, Melissa A. Braddock, "Source Use in A "News Disaster" Account: A Content Analysis of Voter News Service Stories," Journalism \& Mass Communication Quarterly 79, no. 3 (Autumn 2002): 539-558.
} 
ascertain whether the debate over the "missed signals" in each newspaper appeared biased (i.e., framing the issue from a single standpoint) or diverse (i.e., telling the story from both sides). Positions on the divisive issue were coded as defensive, balanced, and critical of the alleged intelligence failure. Defensive views range from the endorsement of government arguments, the criticism of the so-called "finger pointing," or "second guessing," to the opposition to broad investigations into "September 11 lapses." Balanced arguments support efforts to check on flaws, but oppose attempts to play the blame game. Critical positions include suggestions to hold the government accountable, asking for a thorough probe into unheeded attack signs.

Tone analysis: To see how elite newspapers raised the issue on the media agenda, this research weighed whether or not they described the alleged "security lapses" as questionable before May 2002, when disclosures of the government's failure to heed attack signs ignited more attempts to investigate. ${ }^{71}$ An examination of the tone in related stories published before dramatic developments in May 2002 would reveal each newspaper's plan to set the news agenda. Articles in both news and Op-Ed/Commentary categories were part of the sample, but kept distinctively separate. Tones were coded as highly suspicious, somewhat suspicious, or little suspicious of a government ignorance of alarm signals. Highly suspicious tone can be defined as an open, direct or explicit indication of a government inaction on collected intelligence. Stories with somewhat suspicious tone expressed some implicit doubts but stopped short of holding government

71 See timeline in Appendix. 
responsible. In cases where there was no reference, either explicit or implied, to such accusations, they are items without suspicious tone.

These observations were given to each newspaper's coverage to evaluate individual performance. Comparisons were also made to track main patterns in which major newspapers reported the "September 11 lapses" story. Conclusions were based on considerations of the balance of major newspapers' coverage in the debate and their performance to live up to principles set out by the social responsibility theory.

\section{RESULTS AND DISCUSSION}

H1 stated that major newspapers provided adequate information to help foster public understanding and discussion about the "September 11 lapses" controversy. An examination of news frequency, front page placement and length in this study showed that the hypothesis was accepted.

\section{News Frequency}

Overall, in a year from September 12, 2001 to September 11, 2002, the New York Times, Washington Post, San Francisco Chronicle, and USA Today ran a total number of 535 newspaper items (both news and Op-Ed/Commentary articles) which mainly focused on or specifically mentioned to the "September 11 lapses" controversy.

While the newspapers, except the San Francisco Chronicle, ${ }^{72}$ responded to this

\footnotetext{
${ }^{72}$ The San Francisco Chronicle ran its first story on September 11 lapses on September 18, 2001. Carla Marinucci, Michael Taylor, "Questions Why Events Weren't Foreseen," San Francisco Chronicle, 18 September 2001, sec. A, p.3.
} 
story since day one, the most frequently covered period was May 1-June 30, 2002. Fiftyfive percent $(n=292)$ of all selected articles from the four newspapers clustered around this time frame. Little input into the coverage was found in both periods before May and after June 2002. Available items from September 12, 2001 to April 30, 2002, and from July 1 to September 11,2002 comprised $34 \%(n=183)$ and $11 \%(n=60)$ of the sample, respectively. This main pattern was universally reflected in news frequency of each newspaper. (See Table. 1)

New York Times: Fifty-five percent $(\mathrm{n}=106)$ of all sampling items $(\mathrm{n}=192)$ appeared in May and June 2002. Thirty percent $(\mathrm{n}=58)$ were found in seven months before May 2002, while $15 \%(\mathrm{n}=28)$ were published after June 2002 .

San Francisco Chronicle: Sixty-seven percent $(\mathrm{n}=52)$ of all selected items $(\mathrm{n}=$ 77) clustered around May and June 2002. The "September 11 lapses" story was covered with a much lower frequency in months before $(29 \% ; \mathrm{n}=22)$ and after $(4 \% ; \mathrm{n}=3)$.

Washington Post: Available items in May and June 2002 accounted for $48 \%(\mathrm{n}=$ $85)$ of the sample $(\mathrm{n}=178)$. Meanwhile, lower inputs were contributed by periods before May $2002(43 \% ; \mathrm{n}=77)$ and after June $2002(9 \% ; \mathrm{n}=16)$.

USA Today: May-June 2002 was the most frequently covered period, which made up $56 \%(\mathrm{n}=49)$ if the population $(\mathrm{n}=88)$. Available items from September 2001 to April 2002, and from July to September 2002 comprised 29\% $(\mathrm{n}=26)$ and 
$15 \%(\mathrm{n}=13)$, respectively.

Table 1. News Frequency

\begin{tabular}{|l|c|c|c|}
\hline \multicolumn{1}{|c|}{ Paper } & Sept. 12,2001-Apr. 30, 2002 & May 1, 2002-June 30, 2002 & July 1, 2002-Sept. 11, 2002 \\
\hline $\begin{array}{l}\text { New York Times } \\
(\mathrm{n}=192)\end{array}$ & $30 \%(58)$ & $55 \%(106)$ & $15 \%(28)$ \\
\hline $\begin{array}{l}\text { San Francisco Chronicle } \\
(\mathrm{n}=77)\end{array}$ & $29 \%(22)$ & $67 \%(52)$ & $4 \%(3)$ \\
\hline $\begin{array}{l}\text { Washington Post } \\
(\mathrm{n}=178)\end{array}$ & $43 \%(77)$ & $56 \%(49)$ & $9 \%(16)$ \\
\hline $\begin{array}{l}\text { USA Today } \\
(\mathrm{n}=88)\end{array}$ & $29 \%(26)$ & $55 \%(292)$ & $15 \%(13)$ \\
\hline $\begin{array}{l}\text { Totals } \\
(\mathrm{n}=535)\end{array}$ & $34 \%(183)$ & & $11 \%)$ \\
\hline
\end{tabular}

\section{Front-page Placement}

In the sampling frame of 332 items coded as news stories, the four newspapers published 140 articles on the front page. With $42 \%$ of all collected news items appeared on A1, the "September 11 lapses" story was treated as momentous and highly newsworthy. This pattern varied by each newspaper, but front-page items accounted for very high percentages in every individual sample. (See Table. 2)

New York Times: Forty-six percent $(\mathrm{n}=59)$ of all news items $(\mathrm{n}=128)$ was given front-page space.

San Francisco Chronicle: Fifty percent $(\mathrm{n}=12)$ out of 24 collected items appeared on the front page.

Washington Post: Front-page articles made up $43 \%(n=50)$ of available news stories $(n=116)$. 
USA Today: Front-page stories accounted for $30 \%(\mathrm{n}=19)$ of the sample for news items $(n=64)$.

Table 2. Front-page Placement in News Category

\begin{tabular}{|l|c|c|c|}
\hline \multicolumn{1}{|c|}{ Paper } & Number of News Stories & Number of Front-page Stories & Percentage of Total \\
\hline New York Times & 128 & 59 & $46 \%$ \\
\hline San Francisco Chronicle & 24 & 12 & $50 \%$ \\
\hline Washington Post & 116 & 50 & $43 \%$ \\
\hline USA Today & 64 & 19 & $30 \%$ \\
\hline Totals & 332 & 140 & $42 \%$ \\
\hline
\end{tabular}

\section{Length Analysis}

Long stories, which ran 1,000 words or more, constituted $58 \%(\mathrm{n}=192)$ of all items coded as news $(n=332)$ from the four papers. Medium articles with 500 to 999 words represented $36 \%(n=119)$, and short items of under 500 words accounted for 6 $\%(\mathrm{n}=21)$ in the sample. Though the pattern varied from one newspaper to another, the four papers tended to treat "September 11 lapses" as a major story which deserved discussions at a substantial length. (See Table. 3)

New York Times: Long and medium items made up $66 \%(\mathrm{n}=84)$ and $29 \%(\mathrm{n}=$ $37)$ of the sample $(n=128)$, respectively. Meanwhile, only $5 \%(n=7)$ of all available news stories were short items.

San Francisco Chronicle: More than half $(54 \% ; n=13)$ of collected news stories ( $\mathrm{n}=24)$ were long articles, with the remaining half unevenly divided between medium items $(42 \% ; \mathrm{n}=10)$ and short stories $(4 \% ; \mathrm{n}=1)$. 
Washington Post: Sixty-two percent $(\mathrm{n}=72)$ of selected news articles $(\mathrm{n}=116)$ were identified as long stories. Thirty-five point four percent $(n=41)$ were items of medium length, whereas short news articles contributed roughly $2.6 \%(n=3)$ to the population.

USA Today: Although long news items only accounted for $36 \%(\mathrm{n}=23)$ in the sample $(n=64)$, this percentage, together with $48 \%$ contributed by medium articles $(n=$ $31)$, outnumbered the sixteen-percent proportion represented short items $(n=10)$.

Table 3. Analysis of Length in News Category

\begin{tabular}{|l|c|c|c|}
\hline \multicolumn{1}{|c|}{ Paper } & Short Articles & Medium Articles & Long Articles \\
\hline $\begin{array}{l}\text { New York Times } \\
(\mathrm{n}=128)\end{array}$ & $5 \%(7)$ & $29 \%(37)$ & $66 \%(84)$ \\
\hline $\begin{array}{l}\text { San Francisco Chronicle } \\
(\mathrm{n}=24)\end{array}$ & $4 \%(1)$ & $32 \%(10)$ & $54 \%(13)$ \\
\hline $\begin{array}{l}\text { Washington Post } \\
(\mathrm{n}=116)\end{array}$ & $2.6 \%(3)$ & $48 \%(31)$ & $62 \%(72)$ \\
\hline $\begin{array}{l}\text { USA Today } \\
(\mathrm{n}=64)\end{array}$ & $16 \%(10)$ & $36 \%(119)$ & $36 \%(23)$ \\
\hline $\begin{array}{l}\text { Totals } \\
(\mathrm{n}=332)\end{array}$ & $6 \%(21)$ & $58 \%(192)$ \\
\hline
\end{tabular}

This analysis indicated each of the four papers responded to the "September 11 lapses" story with a real focus. They paid attention to the issue from early on. They gave higher priority in front page, space and intensity of coverage to the months of May and June 2002, when dramatic developments of the investigation into intelligence failures 
drew greater public interest. ${ }^{73}$ The intensity of coverage dropped down after June 2002. In the sampling frame of 535 newspaper items, 192 articles were published in the New York Times, 178 in the Washington Post, 77 in the San Francisco Chronicle, and 88 in the USA Today. Given their individual news agenda, priorities and resources, each and all of the four papers provided the public the adequate amount of information to comprehend the "September 11 lapses" controversy.

Findings on frequency, front page and length would be further discussed in a later section, which addresses H3.

H2 predicted major newspapers provided balanced reporting and a forum for exchange of diverse ideas on the issue. Analysis of story treatment, tone and view confirmed this hypothesis.

\section{Story Treatment}

In the sample of 535 newspaper items gathered from four major papers, news stories constituted $62 \%(\mathrm{n}=332)$ against $38 \%$ made up by Op-Ed/Commentary pieces $(n=203)$. The pattern of news articles outnumbering Op-Ed/Commentary items was followed by all newspapers, but the San Francisco Chronicle. (See Table. 4)

San Francisco Chronicle: Sixty-nine percent $(n=53)$ of selected articles $(n=77)$ were Op-Ed/Commentary items, while news stories only represented $31 \%(\mathrm{n}=24)$.

New York Times: News stories outnumbered Op-Ed/Commentary items in the

\footnotetext{
${ }^{73}$ See timeline in Appendix.
} 
sample $(\mathrm{n}=192)$ by thirty-four points: $67 \%(\mathrm{n}=128)$ against $33 \%(\mathrm{n}=64)$.

Washington Post: The difference in the proportions of news stories and OpEd/Commentary items was between $65 \%(n=116)$ and $35 \%(n=62)$.

USA Today: Among 88 sampling items, up to $73 \%(\mathrm{n}=64)$ belonged to news category, while Op-Ed/Commentary pieces made up the remaining $27 \%(\mathrm{n}=24)$.

Table 4. Analysis of Story Treatment

\begin{tabular}{|l|c|c|c|}
\hline \multicolumn{1}{|c|}{ Paper } & News Articles & Op-Ed/Commentary Articles & Total \\
\hline New York Times & $128(67 \%)$ & $64(33 \%)$ & 192 \\
\hline San Francisco Chronicle & $24(31 \%)$ & $53(69 \%)$ & 77 \\
\hline Washington Post & $116(65 \%)$ & $62(35 \%)$ & 178 \\
\hline USA Today & $64(73 \%)$ & $24(27 \%)$ & 88 \\
\hline Totals & $332(62 \%)$ & $203(38 \%)$ & 535 \\
\hline
\end{tabular}

\section{Tone Analysis}

In the sampling frame of 183 newspaper items published by four papers prior to disclosures in May 2002 of intelligence failures, ${ }^{74} 114$ (62\%) were news stories, and 69 (38\%) were Op-Ed/Commentary articles.

Among 114 selected news stories, $38.5 \%(\mathrm{n}=44)$ described the September 11 lapses with highly suspicious tone; $45.5 \%(\mathrm{n}=52)$ implied some doubts, and $16 \%(\mathrm{n}=$ 18) made no accusations of the government's inaction on collected intelligence. (See Table. 5)

\footnotetext{
${ }^{74}$ See timeline in Appendix.
} 
Among 69 collected Op-Ed/Commentary articles, $58 \%(n=40)$ were identified with highly suspicious tone; $29 \%(\mathrm{n}=20)$ fell into the "somewhat suspicious" group, leaving the remaining $13 \%(\mathrm{n}=9)$ for items without any suspicious tone. (See Table. 6) In varied degrees, the main pattern of articles with somewhat and highly suspicious tone outnumbering articles without suspicious tone (both in news and Op-Ed/Commentary categories) were reflected in every newspaper.

New York Times: Prior to May 2002, a total of 58 newspaper items were published, of which $38(65.5 \%)$ were identified as news stories and 20 (34.5\%) were Op-Ed/Commentary articles. Thirty-four percent $(n=13)$ of selected news stories $(n=$ 38) discussed the September 11 lapses with highly suspicious tone; $53 \%(n=20)$ implied some doubts, and $13 \%(\mathrm{n}=5)$ never indicated any accusations. Of 20 selected OpEd/Commentary articles, $65 \%(n=13)$ were identified with highly suspicious tone, $30 \%$ $(n=6)$ were somewhat suspicious, and the remaining $5 \%(n=1)$ was not suspicious at all.

San Francisco Chronicle: Twenty two newspaper items were collected in seven months before May 2002, including 8 news stories (36 \%) and 14 Op-Ed/Commentary articles $(64 \%)$. In the news category $(n=8)$, each group of stories with highly and somewhat suspicious tones made up $37.5 \%$ ( $\mathrm{n}=3$ for each group), while the remaining $25 \%(\mathrm{n}=2)$ were news articles without suspicious tone. Among 14 collected OpEd/Commentary items, $57 \%(n=8)$ addressed the issue with highly suspicious tone, 36 $\%(\mathrm{n}=5)$ expressed some doubts, and $7 \%(\mathrm{n}=1)$ never implied any accusations.

Washington Post: Among 77 newspaper items found, 49 (64\%) were news stories 
and $28(36 \%)$ were Op-Ed/Commentary articles. In news category, stories with highly and somewhat suspicious tone made up $43 \%(\mathrm{n}=21)$ and $45 \%(\mathrm{n}=22)$, respectively of all collected items $(n=49)$. Only $12 \%(n=6)$ of news stories were without suspicious tone. Out of $28 \mathrm{Op}-\mathrm{Ed} / \mathrm{Commentary}$ articles, $46 \%(\mathrm{n}=13)$ fell into the "highly-suspicious" group, the "somewhat-suspicious" constituted $29 \%(\mathrm{n}=8)$, leaving the remaining $25 \%$ $(n=7)$ for the "not-suspicious-at-all" articles.

USA Today: Out of 26 newspaper items found, 19 (73\%) were news stories and 7 (27 \%) were Op-Ed/Commentary articles. Each group of stories with highly and somewhat suspicious tones constituted $37 \%$ ( $n=7$ for each group) of all news articles ( $n$ $=19)$, leaving the remaining $26 \%(\mathrm{n}=5)$ for items without suspicious tone. Up to $86 \%$ $(n=6)$ of selected Op-Ed/Commentary articles $(n=7)$ fell into the "highly-suspicious" group. The "somewhat suspicious" accounted for the remaining 14\% $(\mathrm{n}=1)$. No items were found without suspicious tone.

Table 5. Analysis of Tone in News Articles Published before May 2002

\begin{tabular}{|l|c|c|c|}
\hline \multicolumn{1}{|c|}{ Paper } & Highly suspicious & Somewhat suspicious & Not suspicious at all \\
\hline $\begin{array}{l}\text { New York Times } \\
(\mathrm{n}=38)\end{array}$ & $34 \%(13)$ & $53 \%(20)$ & $13 \%(5)$ \\
\hline $\begin{array}{l}\text { San Francisco Chronicle } \\
(\mathrm{n}=8)\end{array}$ & $37.5 \%(3)$ & $37.5 \%(3)$ & $25 \%(2)$ \\
\hline $\begin{array}{l}\text { Washington Post } \\
(\mathrm{n}=49)\end{array}$ & $43 \%(21)$ & $35 \%(22)$ & $12 \%(6)$ \\
\hline $\begin{array}{l}\text { USA Today } \\
(\mathrm{n}=19)\end{array}$ & $37 \%(7)$ & $45.5 \%(52)$ & $26 \%(5)$ \\
\hline $\begin{array}{l}\text { Totals } \\
(\mathrm{n}=114)\end{array}$ & $38.5 \%(44)$ & $16 \%(18)$ \\
\hline
\end{tabular}


Table 6. Analysis of Tone in Op-Ed/Commentary Articles Published before May 2002

\begin{tabular}{|l|c|c|c|}
\hline \multicolumn{1}{|c|}{ Paper } & Highly suspicious & Somewhat suspicious & Not suspicious at all \\
\hline $\begin{array}{l}\text { New York Times } \\
(\mathrm{n}=20)\end{array}$ & $65(13)$ & $30 \%(6)$ & $5 \%(1)$ \\
\hline $\begin{array}{l}\text { San Francisco Chronicle } \\
(\mathrm{n}=14)\end{array}$ & $57 \%(8)$ & $36 \%(5)$ & $7 \%(1)$ \\
\hline $\begin{array}{l}\text { Washington Post } \\
(\mathrm{n}=28)\end{array}$ & $46 \%(13)$ & $29 \%(8)$ & $25 \%(7)$ \\
\hline $\begin{array}{l}\text { USA Today } \\
(\mathrm{n}=7)\end{array}$ & $86 \%(6)$ & $14 \%(1)$ & $0 \%(0)$ \\
\hline $\begin{array}{l}\text { Totals } \\
(\mathrm{n}=69)\end{array}$ & $58 \%(40)$ & $29 \%(20)$ & $13 \%(9)$ \\
\hline
\end{tabular}

\section{View Analysis}

Critical views were expressed in $51 \%(n=103)$ of all Op-Ed/Commentary items ( $\mathrm{n}=203)$ published by the four newspapers. Thirty-eight percent $(\mathrm{n}=77)$ OpEd/Commentary pieces addressed the "September 11 lapses" with balanced arguments. Items with defensive stance could only make up $11 \%(n=23)$ of the sample.

Though the pattern varied by each newspaper, the New York Times, Washington Post, San Francisco Chronicle and USA Today seemed universally supportive to suggestions to check on flaws. (See Table. 7)

New York Times: Among the sampling items $(\mathrm{n}=64), 52 \%(\mathrm{n}=33)$ expressed views critical to the alleged intelligence failures, $39 \%(\mathrm{n}=25)$ offered balanced comments, and $9 \%(\mathrm{n}=6)$ presented defensive arguments.

San Francisco Chronicle: Items with critical views made up $55 \%(\mathrm{n}=29)$ of the 
sample $(n=53)$. Balanced arguments represented in $28 \%(n=15)$ of all OpEd/Commentary pieces, and defensive comments accounted for the remaining $17 \%(\mathrm{n}=$ 9).

Washington Post: Forty-eight percent $(\mathrm{n}=30)$ of Op-Ed/Commentary items in the sample $(n=62)$ addressed the issue critically; $42 \%(n=26)$ discussed both sides of the story; $10 \%(\mathrm{n}=6)$ defended government's line.

USA Today: Each group of items with critical and balanced views made up $46 \%$ $(\mathrm{n}=11$ for each group) of all selected articles $(\mathrm{n}=24)$, whereas "defensive" items accounted for $8 \%(\mathrm{n}=2)$.

Table 7. Analysis of View in Op-Ed/Commentary Category

\begin{tabular}{|l|c|c|c|}
\hline \multicolumn{1}{|c|}{ Paper } & Critical & Balanced & Defensive \\
\hline $\begin{array}{l}\text { New York Times } \\
(\mathrm{n}=64)\end{array}$ & $52 \%(33)$ & $39 \%(25)$ & $9 \%(6)$ \\
\hline $\begin{array}{l}\text { San Francisco Chronicle } \\
(\mathrm{n}=53)\end{array}$ & $55 \%(29)$ & $42 \%(26)$ & $17 \%(9)$ \\
\hline $\begin{array}{l}\text { Washington Post } \\
(\mathrm{n}=62)\end{array}$ & $48 \%(30)$ & $46 \%(11)$ & $8 \%(2)$ \\
\hline $\begin{array}{l}\text { USA Today } \\
(\mathrm{n}=24)\end{array}$ & $46 \%(11)$ & $38 \%(77)$ & $11 \%(23)$ \\
\hline $\begin{array}{l}\text { Totals } \\
(\mathrm{n}=203)\end{array}$ & $51 \%(103)$ & & 8 (15) \\
\hline
\end{tabular}

These findings suggested that the four papers offered both news and discussion on the "September 11 lapses" controversy. The San Francisco Chronicle, which published more Op-Ed/Commentary items than news articles stood out as the only newspaper 
provided more of public discussion than fact-based reporting on the story. Being an influential regional newspaper on the West Coast, the San Francisco Chronicle had its own priority and agenda in fostering public understanding of the highly national issue.

Though each newspaper followed a different news agenda in covering the controversy, they all tried to tell the issue from both sides, taking the diversity of ideas and perspectives seriously. Before the May 2002 disclosures of intelligence failings leading to the September 11 tragedy, the four papers tended to question the government's inability to prevent terror attacks. In varied degrees, they were inclined to raise the issue with some suspicious tones. The newspapers were more likely to present critical and balanced views in the debate about unheeded attack signs, but did not leave out voices defending the government.

Overall, the four papers served as the authoritative source of information to help understand the complex political universe. They also constituted a forum for exchange of comment and criticism.

Observations on story treatment, tone and views would be further discussed in the next section.

H3 stated that major newspapers played the active role of investigative journalism to serve the people's right to know. These newspapers, as a public watchdog, aggressively checked on losses and failures against government secrecy. Observations on 
manner of reporting, sourcing, author analysis and other findings did not support this hypothesis.

\section{Manner of Reporting}

In the sampling frame of 332 news items gathered from four major papers, $72 \%$ $(n=239)$ were identified as event-based reporting articles. The remaining $28 \%(n=93)$ were counted as original reporting items, which used some form of investigative efforts to report the "September 11 lapses" story. This main pattern was followed by the four newspapers with the San Francisco Chronicle was more likely to depend on covering events when they occurred. (See Table. 8)

San Francisco Chronicle: Eighty-three percent $(\mathrm{n}=20)$ of collected news articles $(n=24)$ represented event-based reporting items. Only $17 \%(n=4)$ were counted as investigative reports.

New York Times: Event-based reporting items made up $71 \%(\mathrm{n}=91)$ in the sample $(n=128)$, while original reporting pieces accounted for $29 \% \quad(n=37)$.

Washington Post: Among 116 sampling news articles, $71 \%(\mathrm{n}=82)$ were eventbased reporting items, and $29 \%(\mathrm{n}=34)$ were investigative reports.

USA Today: Seventy-two percent $(\mathrm{n}=46)$ news stories in the sample $(\mathrm{n}=$ 64) were identified as event coverage. Original reporting items constituted the remaining $28 \%(\mathrm{n}=18)$. 
Table 8. Analysis of Manner of Reporting in News Category

\begin{tabular}{|l|c|c|}
\hline \multicolumn{1}{|c|}{ Paper } & Event-based Reporting & Original Reporting \\
\hline $\begin{array}{l}\text { New York Times } \\
(\mathrm{n}=128)\end{array}$ & $71 \%(91)$ & $29 \%(37)$ \\
\hline $\begin{array}{l}\text { San Francisco Chronicle } \\
(\mathrm{n}=24)\end{array}$ & $83 \%(20)$ & $29 \%(4)$ \\
\hline $\begin{array}{l}\text { Washington Post } \\
(\mathrm{n}=116)\end{array}$ & $71 \%(82)$ & $28 \%(18)$ \\
\hline $\begin{array}{l}\text { USA Today } \\
(\mathrm{n}=64)\end{array}$ & $72 \%(46)$ & $28 \%(93)$ \\
\hline $\begin{array}{l}\text { Totals } \\
(\mathrm{n}=332)\end{array}$ & $72 \%(239)$ & \\
\hline
\end{tabular}

\section{Sourcing Analysis}

Three thousand and eight (3008) sources were found in the sample of 332 news articles published by four major newspapers. Among them, $42.3 \%(n=1273)$ were identified as original sources, $49.8 \%(n=1499)$ were sources from public events. Sources from other media accounted for the remaining $7.9 \%(n=236)$.

The results indicated the papers attempted to reach out for exclusive information on the "missed signals" story, rather than heavily depended on sources from public events or other media. However, the pattern was not reflected in all of the four newspapers. (See Table. 9)

New York Times: In 128 sampling news articles, a total number of 972 sources were found, of which $42 \%(n=413)$ were original. Sources from public events made up $51 \%(n=494)$, leaving the remaining $7 \%(n=65)$ for sources from other media.

San Francisco Chronicle: There were 194 sources used in 24 news stories. Sources from public events made up $53 \%(n=103)$. Eighteen percent $(n=35)$ were 
sources from other media. Only $29 \%(\mathrm{n}=56)$ of all sources were identified as original.

Washington Post: In the sample of 116 news articles, a total number of 1314 sources were found. Original sources and sources from public events accounted for 45.5 $\%(\mathrm{n}=598)$ and $46 \%(\mathrm{n}=605)$, respectively. Only $8.5 \%(\mathrm{n}=111)$ were sources from other media.

USA Today: There were 528 sources used in 64 news stories. Up to $56.3 \%(\mathrm{n}=$ 297) were identified as sources from public events. Thirty-nine percent $(n=206)$ were original sources, leaving the remaining $4.7 \%(\mathrm{n}=25)$ for sources from other media.

Table 9. Analysis of Sourcing in News Category

\begin{tabular}{|l|c|c|c|c|}
\hline \multicolumn{1}{|c|}{ Paper } & Original Source & Source from Public Events & Source from Other Media & Total \\
\hline $\begin{array}{l}\text { New York Times } \\
(\mathrm{n}=128)\end{array}$ & $42 \%(413)$ & $51 \%(494)$ & $7 \%(65)$ & 972 \\
\hline $\begin{array}{l}\text { San Francisco Chronicle } \\
(\mathrm{n}=24)\end{array}$ & $29 \%(56)$ & $53 \%(103)$ & $18 \%(35)$ & 194 \\
\hline $\begin{array}{l}\text { Washington Post } \\
(\mathrm{n}=116)\end{array}$ & $45.5 \%(598)$ & $46 \%(605)$ & $8.5 \%(111)$ & 1314 \\
\hline $\begin{array}{l}\text { USA Today } \\
(\mathrm{n}=64)\end{array}$ & $39 \%(206)$ & $56.3 \%(297)$ & $4.7 \%(25)$ & 528 \\
\hline $\begin{array}{l}\text { Totals } \\
(\mathrm{n}=332)\end{array}$ & $42.3 \%(1273)$ & $49.8 \%(1499)$ & $7.9 \%(236)$ & 3008 \\
\hline
\end{tabular}

\section{Author Analysis}

Certain authors had comparatively big input into the "September 11 lapses" coverage of each newspaper. This finding showed that major papers tended to assign special staff to follow up the momentous and highly newsworthy story. (See Table. 10)

New York Times: Out of 128 selected news items contributed by 45 authors, 26 
articles were authored or co-authored by James Risen (20\%), 24 by David Johnston (19\%), 16 by Alison Mitchell (13\%) and 14 by Don Van Nattar Jr. (11\%).

Washington Post: Fifty-eight authors contributed a total number of 116 news stories. Dan Eggen stood out as the most productive author with 26 articles under his name $(22 \%)$. Walter Pincus and Dana Priest each reported $14 \%(n=16)$ of all collected items.

San Francisco Chronicle: Marc Sandalow and Edward Epstein each authored or co-authored $21 \%(\mathrm{n}=5)$ of the sampling news articles $(\mathrm{n}=24)$. Zachary Coile contributed $17 \%(\mathrm{n}=4)$ of the total.

USA Today: In the sample of 64 news stories, $28 \%(n=18)$ were reported by Kathy Kiely, $25 \%$ by Kevin Johnson $(n=16)$. Toni Locy and John Diamond each authored or co-authored $16 \%(\mathrm{n}=10$ for each author) of all selected items.

Table 10. Most Published Authors in News Category

\begin{tabular}{|l|l|c|}
\hline \multicolumn{1}{|c|}{ Paper } & \multicolumn{1}{|c|}{ Author/Number of Stories } & Percentage of Total \\
\hline New York Times & $\mathrm{n}=128)$ & $20 \%$ \\
& James Risen: 26 & $19 \%$ \\
& David Johnston: 24 & $13 \%$ \\
& Alison Mitchell: 16 & $11 \%$ \\
\hline Washington Post & Don Van Nattar Jr.: 14 & $22 \%$ \\
$(\mathrm{n}=116)$ & Dan Eggen: 26 & $14 \%$ \\
& Walter Pincus: 16 & $14 \%$ \\
\hline San Francisco Chronicle & Dana Priest: 16 & $21 \%$ \\
$(\mathrm{n}=24)$ & Edward Epstein: 5 & $21 \%$ \\
& Marc Sandalow: 5 & $17 \%$ \\
\hline USA Today & Zachary Coile: 4 & $28 \%$ \\
$(\mathrm{n}=64)$ & Kathy Kiely: 18 & $25 \%$ \\
& Kevin Johnson: 16 & $16 \%$ \\
& John Diamond: 10 & $16 \%$ \\
\hline
\end{tabular}




\section{Other Findings}

The aforementioned analyses of tone and view in both news and OpEd/Commentary categories ${ }^{75}$ suggested that the four papers seemed supportive to efforts to check on flaws and hold government accountable. The dominant tones and views expressed in all and each of the papers were generally suspicious and critical of the alleged intelligence lapses. ${ }^{76}$

Nevertheless, the papers lacked follow-up efforts to investigate in an active manner. The time element had implications in many aspects of coverage, indicating that major newspapers mainly rested on reporting events. All of the four papers gave higher priority in front-page placement, space and intensity of coverage to the May-June 2002 period, when dramatic revelations of the "unheeded attack signs" drew greater public interest and fueled the debate over intelligence failures. ${ }^{77}$

New York Times: On average, each day in May and June 2002 had 1.77 articles on the "September 11 lapses," against the rates of 0.25 item/day before May and 0.39 item/day after June. Sixty-one percent $(n=36)$ of all front-page stories $(n=59)$ were run in May and June 2002. Fifty-six percent $(n=47)$ in the total of 84 long items also appeared in this period.

San Francisco Chronicle: On average, each day in May and June 2002 had 0.87

\footnotetext{
${ }^{75}$ For a detailed discussion of this matter see pp. 36-41.

${ }^{76}$ See tables 5,6 , and 7 in pp. $38-40$.

${ }^{77}$ For more details see Appendix.
} 
articles on the alleged intelligence failings, against the rates of 0.1 item/day before May and 0.04 item/day after June. Seventy-five percent $(n=9)$ of all front-page stories $(n=$ 12) appeared in the May-June period. Fifty-four percent $(n=7)$ of collected long articles $(\mathrm{n}=13)$ were published in May and June 2002.

Washington Post: On average, each day in May and June 2002 had approximately 1.42 "missed signals" stories, compared to the rates of 0.34 item/day before May and 0.23 item/day after June. Out of 50 front-page articles collected, $52 \%(n=26)$ were published in May and June 2002. Half $(n=36)$ of the total of 72 long items clustered around this time frame.

USA Today: On average, each day in May and June 2002 had 0.82 "unheeded attack signs" articles, compared to the rates of 0.11 item/day before May and 0.18 item/day after June. Among the total of 19 front-page articles, $53 \%(\mathrm{n}=10)$ were run in May and June 2002. Thirty-five percent $(n=8)$ of all long items were collected in this time frame.

These findings showed that major newspapers were inclined to make the case for efforts to check on what was not done to prevent terrorist attacks. In other words, they tried to speak for and to the public interest to keep government honest and responsible. The papers assigned certain staff-writers covering the "September 11 lapses" story to serve the people's right to know. Attempts were made to reach out for exclusive information to foster public understanding of the divisive and complex issue.

However, major newspapers, as a public watchdog, did not play the active role of investigative journalism. They extensively covered unfolding events when they occurred, 
but stopped short of investigating what they described as an intelligence failure in a persistent and aggressive manner.

One related, intriguing observation gleaned from the coverage: In the first week after the terrorist attacks, all major newspapers raised the question why the U.S. failed to deter September $11 .^{78}$ As early as September 18, 2001 the San Francisco Chronicle broke the news that India had had intelligence on the attacks before they happened and probably passed that information on to U.S. authorities. ${ }^{79}$ The other papers also tried their first independent investigation into possible failures in the month after September $11 .^{80}$ As they already had leads for a major story of national interest, the papers could have pursued expensive investigative projects. Nevertheless, for some reason, they dropped persistent reporting efforts in eight months before May 2002, mainly covered unfolding events. None of four major newspapers dug into the story until May 2002, when dramatic and very public developments fueled the controversy about what had not been done to prevent the September 11 tragedy. The intensity of coverage gradually dropped down

\footnotetext{
${ }^{78}$ The first newspaper articles specifically mentioned to September 11 lapses include: David E. Rosenbaum, "A Day of Terror: The Warnings," New York Times, 12 September 2001, sec. A, p.25; Dal Balz, "Bush Confronts a Nightmare Scenario," Washington Post, 12 September 2001, sec. A, p.2; Richard Willing, Jim Drinkard, "U.S. Under Attack," USA Today, 12 September 2001, sec. A, p.1; Carla Marinucci, Michael Taylor, "Questions Why Events Weren't Foreseen," San Francisco Chronicle, 18 September 2001, sec. A, p.3.

${ }^{79}$ Carla Marinucci, Michael Taylor, “Questions Why Events Weren't Foreseen,” San Francisco Chronicle, 18 September 2001, sec. A, p.3.

${ }^{80}$ Barbara Slavin, Susan Page, “Attacks Throw Harsh Spotlight on C.I.A. Director," USA Today, 24 September 2001, sec.A, p.1; Steve Fairaru, James V. Grimaldi, "FBI Knew Terrorists Were Using Flight Schools," Washington Post, 23 September 2001, sec.A, p.24; Jame Perlez, David E. Sanger, "A Nation Challenged: State Department; Powell Says U.S. Had Signs, But Not Clear Ones, Of a Plot," New York Times, 3 October 2001, sec.A, p.1.
} 
after June 2002, when the Congressional probe into the alleged intelligence lapses produced less significant evidences. ${ }^{81}$ In other words, the newspapers never connected dots or set the public agenda.

H4 predicted major newspapers met criteria listed as required to live up to the established theory of social responsibility. Findings from preceding sections led to the rejection of this hypothesis.

Analyses of news frequency, front-page placement, length confirmed hypothesis 1, which suggested that major newspapers provided adequate information to help foster public understanding and discussion about the "September 11 lapses" controversy. ${ }^{82}$

Analyses of story treatment, tone and view supported hypothesis 2, which predicted the papers provided balanced reporting and a forum for exchange of diverse ideas on the issue. ${ }^{83}$

Observations on manner of reporting, sourcing, author and other findings on tone, view, and the time element rejected hypothesis 3, which stated that the newspapers played the active role of investigative journalism and aggressively checked on losses and failures to serve the people's right to know. ${ }^{84}$

\footnotetext{
${ }^{81}$ See timeline in Appendix.

${ }^{82}$ For a detailed discussion of this matter see pp. 30-34.

${ }^{83}$ For a detailed discussion of this matter see pp. 35-41.

${ }^{84}$ For a detailed discussion of this matter see pp. 41-49.
} 
These results indicated that while major newspapers partially met basic criteria of social responsibility, they failed to fulfill the required function of serving as an aggressive watchdog against government, checking losses and failures. Newspaper coverage of the "September 11 lapses" controversy succeeded in meeting some basic duties: providing full access to the day's intelligence, ${ }^{85}$ including information, discussion, ${ }^{86}$ exchange of comment and criticism ${ }^{87}$ and speaking for and to the public interest in order to hold government accountable. ${ }^{88}$ The newspapers paid attention to the intelligence failures story from early on and gave it a higher priority in all aspects of coverage when dramatic revelations in May and June 2002 drew greater public interest. They offered news and debate on the controversial issue, trying to present it from different views and perspectives.

In the meanwhile, none of the four newspapers adequately fulfilled one of the most important tenets of social responsibility: serving as an aggressive watchdog checking on government. ${ }^{89}$ Though newspaper coverage of the "September 11 lapses" controversy seemed supportive to efforts to check on flaws, it was never an independent investigation into what was not done to prevent terror attacks. The papers tried some investigative attempts, but stopped short of a persistent follow-up to uncover what they

\footnotetext{
${ }^{85}$ Commission on Freedom of the Press, 28.

${ }^{86}$ Siebert, Peterson, Schramm, 74.

${ }^{87}$ Commission on Freedom of the Press, 23.

${ }^{88}$ Schudson, 29.

${ }^{89}$ Siebert, Peterson, Schramm, 74.
} 
described as "intelligence failings." Major newspapers extensively covered dramatic developments when they occurred, but failed to pursue investigative journalism in an aggressive manner.

\section{CONCLUSION}

This content analysis found that the coverage of the "September 11 lapses" was a particular case in which major U.S. newspapers did not live up to journalistic precepts traditionally listed as required for the press to perform socially responsible in a democratic society. The New York Times, Washington Post, San Francisco Chronicle and USA Today were successful in meeting some basic functions set out by the social responsibility theory, but failed to pursue independent investigative journalism as a public watchdog. Major newspapers provided adequate information to foster public understanding and discussion about the controversy. They served as a source of balanced reporting and a forum for exchange of diverse ideas on the issue. In other words, they passed the qualification tests of providing truthful, comprehensive and intelligent accounts of the day's event, ${ }^{90}$ of serving as common carriers of the perspective of the varied groups in society, of representing the public to hold government accountable. ${ }^{91}$ Nevertheless, by failing to aggressively play the role of investigative journalism at a critical time, major

\footnotetext{
${ }^{90}$ Commission on Freedom of the Press, 21.

${ }^{91}$ Schudson, 29.
} 
newspapers missed an important point: to serve as a public watchdog ${ }^{92}$ representing the people's right to know.

The performance of major newspapers at critical times testified to their preeminence as independent institutions at public service. But in this particular case, for some special reason, they retreated from this good tradition.

The magnitude of September 11 and its aftermath suggested some arguments to help explain why major newspapers did not fulfill the socially responsible role as they were supposed to do.

First, media researchers have long pointed out that self-censorship inspired by patriotism often arises during times of insecurities or national disasters. ${ }^{93}$ In emergency cases, prior restraint can be seen as necessary protection of society despite its contradictions to First Amendment principles.

September 11 was not only a sudden disaster, but also a national tragedy which underlined America's vulnerabilities. In the first few months after the terrorist attacks, the temptation of censorship or self-censorship was present. The government attempted to control news content, asking the media to honor restrictions for the sake of national security. ${ }^{94}$ According to a Pew survey, the public endorsed censorship in responding to the question: "which is more important to you, that the government be able to censor

\footnotetext{
${ }^{92}$ Siebert, Peterson, Schramm, 74.

${ }^{93}$ Gary, An American Paradox: Censorship in a Nation of Free Speech, 133.

${ }^{94}$ Scott Lucas, "How a Free Press Censors Itself," New Statesman 130, no. 4563 (12 November 2001): 1415.
} 
news stories it feels threaten national security, or that the news media be able to report stories they feel are in the national interest?"95 American journalists had to walk a fine line between warnings about undermining national security and the fear that they were not playing their vital watchdog role. ${ }^{96}$ The question of where to draw the line between nationalism and objectivity was a tough one for many reporters. ${ }^{97}$ In the wake of September 11, while the desire to have the "why-it-could-happen" question answered was compelling, Congressional leaders decided to forgo an immediate inquiry into the intelligence lapses. They stated it would not be appropriate to conduct such an investigation, which threatened to demoralize the nation in the new war on terrorism. ${ }^{98}$

The current research did not go far enough to explore whether the New York Times, Washington Post, San Francisco Chronicle, USA Today, in responding to a natural tendency of being part of the patriotic fervor, exercised self-censorship in their coverage of the "September 11 lapses." But media experts observed many instances in which American journalists lost sight of their duty under the unique circumstance of September 11. They either found themselves hard to be critical when the audience was swept up in patriotism, ${ }^{99}$ or paid a price for being critics when Americans did not want

\footnotetext{
${ }^{95}$ Cross, “'New America’ May Forget Old Values,” 4.

96 Trombly, "Ethics and War," 14.

${ }^{97}$ Barton, Campbell, "Patriotism and the News," 18-21.

98 James Risen, Todd S. Purdum, “A Nation Challenged: The Politics of Intelligence,” New York Times, 23 November 2001, sec. B, p.5.

99 Trombly, 14-18.
} 
critics. $^{100}$

Second, as the carry-over from September 11, the subsequent war in Afghanistan became the biggest concern both at home and abroad for a substantial period of time. With the shock of terror attacks lingering, the "America Fights Back" story was right in the center of hot news cycle. American newspapers, therefore, invested huge resources and efforts in covering the conflict. As a result, they carried more stories about Afghanistan on page one in the four months since September 11 than the previous four decades. ${ }^{101}$ The intense coverage of the war in Afghanistan might arguably have distracted major newspapers from digging into the controversy over the government's failure to prevent terrorist attacks. When the Afghan war overwhelmingly dominated the media agenda, the "September 11 lapses" story was possibly relegated to a lower priority. It could only emerge as breaking news later, when the Afghanistan story wore off, and dramatic developments in the investigation into intelligence failings caught public attention.

This research, qualitative by nature, did not show any generalizable evidences to confirm these arguments. It just indicated newspaper coverage of the controversy stopped short of an aggressive and persistent effort to pursue independent investigative journalism, thereby failing to live up to the tenets of social responsibility.

\footnotetext{
${ }^{100}$ Barton, Campbell, 18-21.

${ }^{101}$ Michael Parks, "Foreign News: What's Next," Columbia Journalism Review 40, no. 5 (January/February 2002): 52-57.
} 
The fact is by pointing out a phenomenon without factually explaining its causes the present research exposes its biggest limitation. Future research could conduct interviews with newspaper reporters and editors who know better than anyone what key factors affected the balance of the "September 11 lapses" coverage. Their stories would offer important insights into the craft of each media message.

There is another limitation in the research that must be mentioned. The inclusion of the San Francisco Chronicle in the sample was a reluctant choice because this author was not able to retrieve related articles published by the Los Angeles Times from the LexisNexis database. The Los Angeles Times has long established itself as part of the elite press and the top newspaper on the West Coast. It is the best candidate to join the New York Times, Washington Post, and USA Today in any research on major newspapers. However, the Lexis-Nexis search machine denies any attempts to retrieve Los Angeles Times articles as far back as the year from September 12, 2001 to September 11, 2002. Being the second largest newspaper on the West Coast, the San Francisco Chronicle constituted an influential regional voice rather than a national one. Its coverage of the "September 11 lapses" produced a total number of 77 articles, including 53 OpEd/Commentary items and 24 news stories. With Op-Ed/Commentary articles outnumbering news stories, the San Francisco Chronicle stood out as the only newspaper in the sample provided more of discussion than fact-based reporting on the issue. This distinctive manner of coverage indicated the paper had its own priority and agenda in fostering public understanding of the highly national controversy. This posed difficulties 
to comparative analysis of its work and the performance of the three national newspapers - New York Times, Washington Post, and USA Today.

Despite all of the shortcomings, the present search provides a means to understand a particular application of social responsibility principles in the operation of today's press.

Various studies have been conducted concerning different aspects of September 11 and the media, but this is one of the first to examine the coverage of the controversy over government's failures to deter terror attacks. The story itself stirred up debates until late July 2004, when a bi-partisan commission appointed by the Congress released its final report on intelligence failings leading up to September 11.

The underlying argument, suggested by this research, is that the press theory of social responsibility can be tested in an exemplary scenario. One barometer of the principles of social responsibility is that whether these ideals exist even in dilemma situations, where the temptation of compromise is as compelling as the desire for integrity.

The analysis of the "September 11 lapses" coverage recorded a particular instance in which major newspapers failed to play their vital watchdog role at a critical but very sensitive time. With disclosures of government's failure to act on collected intelligence, major newspapers faced the moment of truth to serve the people's right to know. But for some reason, they dropped independent investigative efforts, resting themselves on events coverage. The papers did not really dig in the story until dramatic developments changed their course. Once no more revelations was made public, they backed off from persistent 
follow-ups.

This leads to a larger consideration. The social responsibility theory, which emphasizes the watchdog role of the media, is considered as one of the most fundamental and distinguished elements of the press operation in America. But in his Rich Media, Poor Democracy: Communication Politics in Dubious Times, McChesney mentioned to a decline, even collapse, of journalism as a public service in every facet of the media. ${ }^{102} \mathrm{He}$ argued that the time-consuming and expensive investigative journalism "looking into subjects that raise any questions about the ultimate legitimacy of our ruling institutions is not welcome" 103 in the domain of what he described as the "for-profit and corporate media system."104 Social responsibility theory accepts the need for the press as an institution to maintain "its own financial self-sufficiency so as to be free from the pressures of special interests." 105 However, the commercial aims of the news operation at times conflict with the journalistic precepts traditionally listed as required for the press in a democratic society. The question is if it is realistic to measure the performance of today's press against the established imperatives of social responsibility.

With all of the strengths and weaknesses, this research is beneficial as a steppingstone for future consideration on the same topic. Later projects may examine such noteworthy issues as typical applications of the social responsibility doctrine in the

\footnotetext{
${ }^{102}$ McChesney, Rich Media, Poor Democracy, 51.

${ }^{103}$ Ibid., 61-62.

${ }^{104}$ Ibid., ix.

105 Siebert, Peterson, Schramm, 74.
} 
operation of today's press or the relevance of this theory in the current structure and new trends of American media. 


\section{APPENDIX}

\section{Key Dates in the "Sept. 11 Lapses" Controversy: A Timeline}

September 2001

A day after Sept. 11, question was raised about why the intelligence services failed to deter terror attacks. President Bush and U.S. intelligence leaders said they had no warnings to prepare for the attacks.

October 2001

U.S. intelligence outlined a cryptic message intercepted on the eve of Sept. 11 in which a Qaeda member said Osama bin Laden was planning a Hiroshima.

News emerged that top Justice Department officials turned down a request by FBI agents in Minnesota for a warrant to gather information on a suspect who was supposed to have taken part in the terrorist plot.

American and allied forces launched the war in Afghanistan against terrorism.

November 2001

Congressional leaders agreed to delay a thorough investigation into government's failure to deter Sept. 11, citing the need to give the administration time to focus on the war on terrorism. 
December 2001

Zacarias Moussaoui, a terror suspect, was indicted. He was arrested before the terrorist attacks and later considered a material witness in the Sept. 11 probe.

January 2002

Bush, seeking to restrict investigations into Sept. 11 events, asked House and Senate leaders to allow only two congressional committees to probe the government's response to terrorist attacks.

February 2002

Congressional intelligence committees announced a joint investigation into whether intelligence failures left American vulnerable to the terror attacks.

CIA Director George Tenet, in his first appearance before Congress since Sept. 11, rejected suggestion that U.S. intelligence services had failed to anticipate the attacks.

March 2002

INS was under heavy scrutiny for letting Sept. 11 hijackers into the United States for granting two of them visas after they were killed in the attacks.

April 2002

Brit Snider, lead investigator of the House-Senate inquiry resigned under pressure. Eleanor Hill succeeded her by May 2002. 
May 2002

Public interest in the case grew with the disclosures of F.B.I. field reports from Phoenix and Minneapolis in summer 2001 about potential terrorist threats in flight schools, and news of Mr. Bush's intelligence briefing on Aug. 6, 2001 in which some attack signs were ignored by the President. The Democrats questioned how much Bush knew before Sept. 11 and urged for an independent commission to investigate. The administration reacted angrily. Bush opposed to establishing the proposed commission.

F.B.I. Director Robert Mueller took the heat for his untrue statements. For the first time, he acknowledged that Sept. 11 might have been preventable if F.B.I. responded differently to all the pieces of available information.

Dan Rather said journalists had not been properly investigating since Sept. 11. He described the pressures to conform that built up after the attacks.

June 2002

Congressional hearings began. Witnesses testified, revealing important details of Sept. 11 lapses. A Congressional committee questioned intelligence officials about missed warnings of terrorist attacks. Chiefs of the F.B.I., C.I.A. and National Security Agency detailed the missed clues pointing to Sept. 11.

In an interview with the New York Times Egyptian Hosni Mubarak said that his country's intelligence service warned U.S. officials about a week before Sept. 11, 2001 that alQaeda was in the advanced stage of preparing an attack on America. President Bush dismissed Mubarak's claims. He said: "I see no evidence today that said this country 
could have prevented the attacks."

July 2002

A Congressional panel released a report on flaws that allowed Sept. 11 events. Pressure expanded for the inquiry into intelligence lapses. A surprise House vote raised the possibility that Bush might be forced to accept an independent commission.

August 2002

German authority said the al-Qaeda cell in Hamburg identified the World Trade Center as a target more than a year before Sept. 11, 2001.

September 2002

White House first agreed on an independent commission, but then backed off. Investigators concluded U.S. intelligence services failed to adequately scrutinize information they received before Sept. 11 about the terrorist plot.

First anniversary of Sept. 11 tragedy. 


\section{BIBLIOGRAPHY}

Altschull, J. Herbert. Agents of Power: The Role of the News Media in Human Affairs. New York: Longman, 1984.

. From Milton to McLuhan: The Ideas Behind American Journalism. New York \& London: Longman, 1990.

Anderson, Rob, Robert Dardenne, and George M. Killenberg. The Conversation of Journalism: Communication, Community, and News. Westport, Connecticut: Praeger, 1994.

Bagdikian, Ben H. The Media Monopoly, 6th ed. Boston: Beacon Press, 2000.

Balz, Dal. "Bush Confronts a Nightmare Scenario." Washington Post, 12 September 2001.

Barton, Gina, and Beverly Campbell. "Patriotism and the News." Quill 89, no. 10 (December 2001): 18-21.

Birkland, Thomas A. After Disaster: Agenda Setting, Public Policy, and Focusing Events. Washington, D.C.: Georgetown University Press, 1997.

Carter, R. F., K. R. Stamm, and K. Heintz-Knowles. "Agenda Setting and Consequentiality.” Journalism Quarterly 69 (1992): 868-877.

Cloud, Stanley W. "The Pentagon and the Press." Nieman Reports 55, no. 4 (Winter 2001): 13-16.

Cohen, Bernard C. The Press and Foreign Policy. Princeton, N.J.: Princeton University Press, 1963.

Commission on Freedom of the Press. A Free and Responsible Press. Chicago: University of Chicago Press, 1947.

Cornwell, Elmer E. The Presidency and the Press. Morristown, N.J.: General Learning Press, 1974.

Cross, Al. “"New America' May Forget Old Values.” Quill 90, no. 1 (January/February 2002): 4. 
Danielian, L.H., and S. D. Reese. "A Closer Look at Intermedia Influences on Agenda Setting: The Cocaine Issue of 1986." In Communication Campaigns About Drugs: Government, Media, and the Public, ed. P. J. Shoemaker, 47-66. Hillsdale, N.J.: Lawrence Erlbaum, 1989.

Dunham, Corydon B. Fighting for the First Amendment: Stanton of CBS vs. Congress and the Nixon White House. Westport, Connecticut: Praeger, 1997.

Fairaru, Steve, James V. Grimaldi. "FBI Knew Terrorists Were Using Flight Schools." Washington Post, 23 September 2001.

Gade, Peter et al. "Journalists' Attitudes Toward Civic Journalism Media Roles." Newspaper Research Journal 19, no. 4 (Fall 1998): 13-26.

Garry, Patrick. An American Paradox: Censorship in a Nation of Free Speech. Westport, Connecticut: Praeger, 1993.

Gurevitch, M., and J. G. Blumler. "Political Communication Systems and Democratic Values." In Democracy and the Mass Media, ed. J. Lichtenberg, 269-289. Cambridge, Eng.: Cambridge University Press, 1990 .

Kurtz, Howard. "More Reporting By Times Writer Called Suspect." Washington Post, 8 May 2003.

Lang, Gladys Engel, and Kurt Lang. The Battle for Public Opinion: The President, the Press and the Polls During Watergate. New York: Columbia University Press, 1983.

Lang, Kurt, and Gladys Engel Lang. "The Mass Media and Voting." In American Voting Behavior, eds. E. Burdick, A. J. Brodbeck, 217-235. Glencoe, Ill.: The Free Press, 1959.

Lippman, Walter. Public Opinion. New York: The Free Press, 1965.

Liston, Robert A. The Right to Know: Censorship in America. New York: Franklin Watts, Inc., 1973.

Long, Norton E. "The Local Community as an Ecology of Games." American Journal of Sociology 64 (1958): 251-261. 
Lowery, Shearon A., and Melvin L. DeFleur. Milestone in Mass Communication Research: Media Effects. 3d. ed. New York: Longman Publishers USA, 1995.

Lucas, Scott. "How a Free Press Censors Itself." New Statesman 130, no. 4563 (12 November 2001): 14-15.

Marinucci, Carla, Michael Taylor. "Questions Why Events Weren't Foreseen." San Francisco Chronicle, 18 September 2001.

McChesney, Robert W. Rich Media, Poor Democracy: Communication Politics in Dubious Times. Urbana \& Chicago: University of Illinois Press, 1999.

McCombs, Maxwell E., and Donald L. Shaw. "The Agenda-Setting Function of Mass Media." Public Opinion Quarterly 36, no. 2 (Summer 1972): 176-187.

Nerone, John C, ed. Last Rights: Revisiting Four Theories of the Press. Urbana: University of Illinois Press, 1995.

Parks, Michael. "Foreign News: What's Next." Columbia Journalism Review 40, no. 5 (January/February 2002): 52-57.

Perlez, Jame, David E. Sanger. "A Nation Challenged: State Department.” New York Times, 3 October 2001.

Perry, David K. Theory and Research in Mass Communication: Contexts and Consequences. Mahwa, New Jersey: Lawrence Erlbaum Associates Publishers, 2002.

Porter, William E. Assault on the Media: The Nixon Years. Ann Arbor: The University of Michigan Press, 2001.

Risen, James, Todd S. Purdum. "A Nation Challenged: The Politics of Intelligence." New York Times, 23 November 2001.

Rosen, Jay. "Politics, Vision, and the Press: Toward a Public Agenda for Journalism." In The New News v. the Old News: The Press and Politics in the 1990s, eds. J. Rosen and P. Taylor, 1-33. New York: The Twentieth Century Fund, 1992.

Rosenbaum, David. “A Day of Terror: The Warnings.” New York Times, 12 September 2001

Severin, Werner J., and James Tankard, Jr. Communication Theories: Origins, Methods, and Uses in the Mass Media. New York: Longman, 2001. 
Schudson, Michael. The Power of News. Cambridge, MA: Harvard University Press, 1995.

Shaw, Donald. L., and S. E. Martin. "The Function of Mass Media Agenda Setting.” Journalism Quarterly 69 (1992): 902-920.

Shepard, A. C. “The Gospel of Public Journalism.” American Journalism Review 16 (1994): 28-35.

Siebert, Fred S., Theodore Peterson, and Wilbur Schramm. Four Theories of the Press. Urbana: University of Illinois Press, 1956.

Slavin, Barbara, Susan Page. "Attacks Throw Harsh Spotlight on C.I.A. Director." USA Today, 24 September 2001.

Smith, Conrad. Media and Apocalypse: News Coverage of the Yellowstone Forest Fires, Exxon Valdez Oil Spill, and Lora Prieta Earthquake. Westpoint, Conn.: Greenwood Press, 1992.

Sumpter, Randall, S., and Melissa A. Braddock. "Source Use in A "News Disaster" Account: A Content Analysis of Voter News Service Stories." Journalism \& Mass Communication Quarterly 79, no. 3 (Autumn 2002): 539558.

Teeter, Dwight L., Jr., Bill Loving. Law of Mass Communications: Freedom and Control of Print and Broadcast Media. 10th ed. New York: Foundation Press, 2001.

Trombly, Maria. "Ethics and War.” Quill 89, no. 10 (December 2001): 14-17.

Willing, Richard, Jim Drinkard. "U.S. Under Attack." USA Today, 12 September 2001. 